\title{
Epidemiology of mesothelioma on Walcheren Island
}

\author{
J. STUMPHIUS \\ Bedrijfsarts van de N.V. Kon. Mij 'De Schelde', Scheepswerf en Machinefabriek, \\ Vlissingen, The Netherlands
}

\begin{abstract}
Stumphius, J. (1971). Brit. J. industr. Med., 28, 59-66. Epidemiology of mesothelioma on Walcheren Island. The chance finding of asbestos bodies without 'asbestosis' in the lungs of a shipyard worker who had not worked directly with asbestos led to this investigation into the relationship between asbestos bodies in the sputum, occupation, and mesothelioma in the shipyard at Vlissingen on Walcheren Island. Examination of the sputum from a sample of 277 shipyard workers from various occupation groups (excluding insulation workers and others known to work continuously with asbestos) showed 'asbestos' bodies to be present in $60 \%$. The frequency varied from $39 \%$ in workers with no obvious exposure to asbestos dust to $100 \%$ among those with slight but definite exposure. By repeating the analysis using the occupations 5 to 10 years previously it was found that many of the workers currently employed in occupations not exposed to asbestos who had asbestos bodies in their sputum had been exposed in the past.

Between 1962 and 1968, 25 cases of mesothelioma were discovered on Walcheren; of these, 22 cases had been employed in the shipyard at some time and their actual job was known in all but one case. The shipyard employs approximately 3000 men so that the attack rate for mesothelioma was approximately 100 per 100000 males per year. For Dutch provinces with heavy industry the rate is 1.0 per 100000 per year. For the different occupational categories within the shipyard the rates varied from approximately 50 for 'clean work' to 280 for men with some exposure to asbestos dust. Asbestos insulation workers were not included in the study and no cases of mesothelioma came from that occupational group.
\end{abstract}

Asbestos is a mineral widely used for an ever increasing number of purposes on account of its fibrous structure, its many practical applications, and its low cost.

The medical consequences of contact with asbestos are twofold, namely, asbestosis (frequently coupled with a high incidence of bronchial carcinoma) as a typical occupational disease of asbestos workers, and diffuse mesothelioma associated with slight exposure to asbestos in the distant past. In addition, asbestos leads to the formation of asbestos bodies and also of pleural plaques which appear (as yet) to be non-malignant.

Diffuse mesotheliomas, until recently held to be extremely rare, have been reported in increasing numbers in the past few years.

The majority of recent publications are of AngloSaxon origin and demonstrate some connexion either direct or indirect - with the asbestos industry as such or with heavy industry in general (Wagner, Sleggs, and Marchand, 1960; Gilson, 1966).

The Netherlands has never had a large asbestos industry but heavy industry is well represented, particularly in the western provinces of Zeeland, North Holland, and South Holland. Zeeland lies on the delta of the rivers Rhine and Scheldt, in the south-west of the country. It consists of a number of linked islands, a circumstance which has tended 
to isolate it from the rest of the Netherlands. It is primarily an agricultural province. The most important island is Walcheren (90000 inhabitants) with the county seat of Middelburg at its centre and the port and industrial town of Vlissingen on the south coast.

Until recently; almost the only local industry was the large shipyard and engineering works of N.V. Koninklijke Maatschappij 'de Schelde' (Royal Schelde) established in Vlissingen a century ago. At present this firm has some 3100 employees on its payroll. A considerable proportion of the inhabitants of Walcheren work there and the labour turnover is relatively low.

At the time when this investigation was carried out the situation was as follows:

For many years shipbuilding, including naval vessels, was the firm's main activity. More recently the emphasis has changed to other industrial products and to ship repairs.

Asbestos had been widely used in shipbuilding, especially in the past, as it meets the high standards required for insulation and fire prevention in seagoing vessels.

Insulation work was never done by the firm's own employees. It was always carried out by the personnel of an insulating firm regularly engaged as subcontractor. Intensive occupational exposure of the Royal Schelde's own employees to asbestos dust did not occur. But of course asbestos cannot be excluded as a source of slight exposure in many departments of the firm.

Asbestosis used seldom to be found in the Netherlands. Undoubtedly this was partly due to professional unfamiliarity with the possibility of the disease. But the insulation workers had been examined and seven asbestosis cases were found out of a total of 24 workers.

Among Royal Schelde employees the most detailed investigation and examination had failed to bring even one case of asbestosis to light. Asbestos seemed to represent no danger to the firm's own employees until two discoveries were made which seemed to contradict this.

(1) Necropsy performed on the body of an employee of the firm who had died as the result of an accident revealed countless asbestos bodies in the lungs. There was no fibrosis so that asbestosis was not diagnosed. During his lifetime the man had never suffered from any serious illness of the respiratory tract. What was striking was the presence in the lungs of large quantities of iron pigment, both in the macrophages and in the form of amorphous particles. The origin of these was obvious. There is always a great deal of exposure to iron oxides in a shipyard. Moreover, the victim had spent years as an electric welder. Heavy occupational exposure to asbestos had not occurred. The man himself had never actually worked with asbestos, nor were welding electrodes covered with asbestos ever used by this firm.

(2) In 1966, three cases of mesothelioma were diagnosed in men who had been employed in the shipyard.

\section{Methods}

\section{Sputum examination}

Workers were asked to bring fresh specimens of sputum for examination. They were encouraged to bring sputum produced during acute respiratory illnesses so that specimens were obtained from men with and without a chronic productive cough.

At least two thick smears were made, dried, and stained with Perl's iron stain. Only specimens of sputum containing alveolar macrophages were examined for asbestos bodies. The slides were examined under low power, and suspected asbestos bodies were re-examined under higher magnification. When asbestos bodies were not found on the direct smear, specimens containing alveolar macrophages were re-examined after digestion with $1 \%$ sodium carbonate for 24 hours at $37^{\circ} \mathrm{C}$. The sediment was separated by centrifuge and washed repeatedly with water before re-examination. No difficulty was encountered in distinguishing typical asbestos bodies from other iron pigment in the sputum.

Sputum specimens were considered positive for asbestos bodies if any were found. No attempt was made to grade the specimens according to the number of bodies.

\section{Mesotheliomas}

Walcheren has a central pathology laboratory and, with the close cooperation of the pathologists and physicians on the island, it was possible to follow up and investigate fully many suspected cases of mesothelioma. Wherever possible the final diagnosis was made on postmortem findings but in some cases it rested on biopsy combined with typical clinical findings. The criteria for diagnosis were those recommended by the UICC Working Group on Asbestos and Cancer in their 1965 report.

\section{Occupational classification}

Because both in the sputum containing asbestos bodies and in the lungs of patients dying of mesothelioma the asbestos bodies were always associated with other ironcontaining material, the workers were classified according to their exposure both to iron oxides or fumes and to asbestos. The men employed by contractors on insulation were not studied so that no men were regarded as working with asbestos or as being heavily exposed to its dust. However, those craftsmen who were employed in finishing ships inevitably had some exposure to asbestos dust because it was at this time that insulation work was being done. Similarly, craftsmen doing repair work were also exposed if insulation was being removed or replaced at the same time. The following categories were recognized:

I Iron vapour: Apparently negligible asbestos exposure - welders and cutters

II Iron oxides (rust): Some exposure to asbestos fitters, welders, plumbers, etc. employed after launching or during repairs 
III Iron vapour and rust : apparently negligible asbestos exposure - platers, shipwrights, and foundrymen employed on initial construction

IV Men exposed to other dust, including some asbestos, not exposed to iron vapour or rust: painters, carpenters, etc. employed after launching or during repairs

$\mathrm{V}$ Not apparently exposed to iron vapour or rust nor to asbestos dust.

This classification was applied to the total working population in the shipyard at the time of the sputum study and mesothelioma study. It was also applied to the same men according to their occupation within the shipyard 5 to 10 years previously. This was necessary because although the turnover of labour was low there was a tendency for men to move within the firm to lighter and cleaner jobs as they grew older. The information available about the occupational classification of the labour force over 10 years before the investigation was incomplete.

\section{Results}

\section{Asbestos bodies}

During the five-year period specimens of alveolar sputum from 277 Royal Schelde employees were examined. Asbestos bodies were found in 160 $(57 \cdot 8 \%)$.

In Table 1 the results of the sputum examination are related to the occupation of the men at the time of the investigation and to the total numbers in each occupational group.

A remarkably high proportion of positives are found in the group 'clean work' (V). The occupational history of all those examined was extended to cover the work they had been doing 5 to 10 years previously (Table 2). Classification on the latter basis showed a considerable shift from the clean work category to that of other exposure groups.
Of the original $63(39 \%)$ positives in group $\mathrm{V}$, only $33(26 \%)$ remained.

In Table 2 the percentage of positive sputa in group $\mathrm{V}$ proved to differ significantly from that in groups I to IV $\left(\chi^{2}=104.1\right.$; D.F. 4 ; P $\left.<0.001\right)$.

There also proved to be significant differences between the four groups I to IV $\left(\chi^{2}=8 \cdot 13\right.$, D.F. 3; $P<0.05$ ).

It is fair to assume that if the work history were extended to cover even more of the past an increasing number of the positives in group $\mathrm{V}$ would have to be re-classified.

The variation between the four groups I to IV appears to be related to the possibility of exposure to asbestos in that groups II and IV contained the highest proportion of positives. The sputa from group II, in which rust exposure was combined with possible exposure to asbestos, all contained asbestos bodies.

The findings are consistent with the suggestion that the high proportion of sputa positive for asbestos bodies found in this investigation were due to inhalation of asbestos at work. The frequency of positive sputa appears to be related to the extent of the exposure possibly augmented by inhalation of rust.

\section{Mesotheliomas}

Mesothelioma was diagnosed in 25 cases during the seven years 1962-68. Of these, 22 were confirmed histologically, 7 by both biopsy and necropsy, 4 by necropsy, and 11 by biopsy plus clinical findings. In the remaining 3 cases the diagnosis was based on typical clinical findings and course but histological confirmation was not available. In all 11 necropsy cases numerous asbestos bodies were found in the

TABLE 1

Finding of Asbestos Bodies in Sputum related to Current Occupation

\begin{tabular}{|c|c|c|c|c|c|c|c|c|c|c|c|c|c|c|c|c|c|c|c|c|c|c|}
\hline \multirow{3}{*}{$\begin{array}{l}\text { Exposure group } \\
\quad(\text { see text) }\end{array}$} & \multicolumn{21}{|c|}{ Age group } & \multirow{3}{*}{$\begin{array}{c}\% \\
\text { positive } \\
\text { of sputa } \\
\text { examined }\end{array}$} \\
\hline & \multicolumn{3}{|c|}{$15-19$} & \multicolumn{3}{|c|}{$20-29$} & \multicolumn{3}{|c|}{$30-39$} & \multicolumn{3}{|c|}{$40-49$} & \multicolumn{3}{|c|}{$50-59$} & \multicolumn{3}{|c|}{$60-65$} & \multicolumn{3}{|c|}{ Total } & \\
\hline & $A$ & $B$ & $\bar{C}$ & $A$ & $B$ & $\bar{C}$ & $A$ & $B$ & $C$ & $A$ & $B$ & $C$ & $A$ & $B$ & $C$ & $A$ & $B$ & $C$ & $A$ & $B$ & C & \\
\hline $\begin{array}{l}\text { I Iron vapour ... } \\
\text { II Rust and some }\end{array}$ & 2 & 0 & 0 & 36 & 2 & 2 & 63 & 6 & 2 & 136 & 12 & 9 & 75 & 3 & 3 & 17 & 4 & 3 & 329 & 27 & 19 & $70 \cdot 4$ \\
\hline $\begin{array}{l}\text { asbestos } \\
\text { III Iron vapour and }\end{array}$ & 7 & 0 & 0 & 42 & 1 & 1 & 37 & 5 & 5 & 54 & 4 & 4 & 35 & 5 & 5 & 13 & 6 & 6 & 188 & 21 & 21 & 100 \\
\hline $\begin{array}{c}\text { rust } \ldots \\
\text { IV Some asbestos but }\end{array}$ & 61 & 0 & 0 & 67 & 4 & 2 & 57 & 4 & 3 & 114 & 13 & 11 & 99 & 21 & 18 & 26 & 7 & 6 & 424 & 49 & 40 & $80 \cdot 2$ \\
\hline $\begin{array}{l}\text { little iron } \\
\text { vapour or rust }\end{array}$ & 4 & 0 & 0 & 47 & 1 & 0 & 56 & 1 & 0 & 79 & 7 & 6 & 89 & 5 & 5 & 37 & 6 & 6 & 312 & 20 & 17 & 85 \\
\hline V Clean work & 161 & 1 & 0 & 285 & 5 & 1 & 275 & 12 & 6 & 469 & 44 & 13 & 472 & 49 & 22 & 187 & 49 & 21 & 1849 & 160 & 63 & $39 \cdot 4$ \\
\hline Total & 235 & 1 & 0 & 477 & 13 & 6 & 488 & 28 & 16 & 852 & 80 & 43 & 770 & 83 & 53 & 280 & 72 & 42 & 3102 & 277 & 160 & \\
\hline $\begin{array}{r}\% \text { positive of sputa } \\
\text { examined } . .\end{array}$ & & 0 & & & $6 \cdot 2$ & & & $57 \cdot 1$ & & & $53 \cdot 8$ & & & 63.9 & & & $58 \cdot 8$ & & & $57 \cdot 8$ & & \\
\hline
\end{tabular}

$A=$ total working population; $B=$ number of men from whom sputa were examined; $C=$ number of sputa positive for asbestos bodies 
TABLE 2

Finding of Asbestos Bodies in Sputum Related to OCCupation 5 to 10 Years Previously

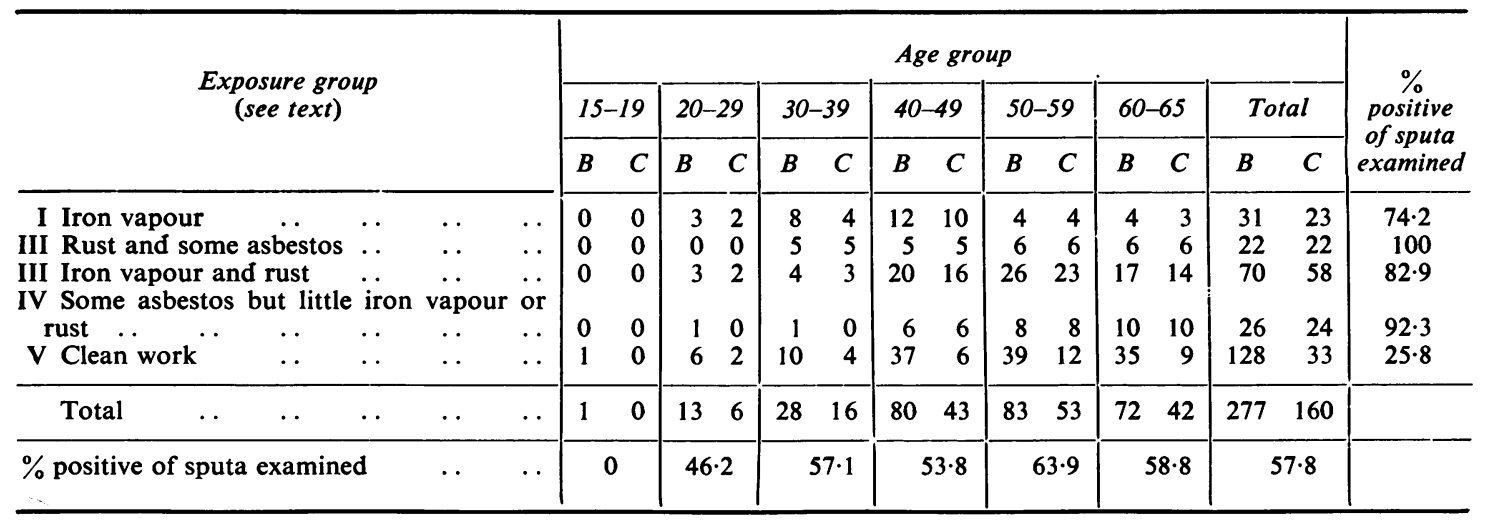

$B=$ number of men from whom sputa were examined; $C=$ number of sputa positive for asbestos bodies.

underlying and in the contralateral lung in both section and smear. In 4 of the non-necropsy cases asbestos bodies were found in the sputum. A large quantity of iron pigment, other than that forming the asbestos bodies, was found in all these lungs and sputa. In 2 of the necropsy cases, asbestos bodies from the lung smears were examined with the electron microscope. Chrysotile and amphibole asbestos fibres were identified in each case (Stumphius and Meyer, 1968).

In 19 of the 25 cases the tumour originated in tne pleura, in 4 cases it originated in the peritoneum, and in 2 cases there was a combination tumour in both pleura and peritoneum and it was impossible to decide the site of origin.

The clinical course of the illness in the pleural cases was usually associated with a characteristic posture (Figs 1 and 2). These illustrate a typical case of right-sided pleural mesothelioma in which symptoms started when the patient was aged 60; he died 18 months later. He was thought initially to have had a pulmonary embolism because of a blood-stained effusion with underlying lung atelectasis. As the disease progressed and a thick rind of tumour formed around the lower part of the right lung, the right half of the thorax diminished in size. This was associated with a characteristic stoop due to a scoliosis to the right which is well shown in the photographs.

\section{Occupation and mesothelioma}

As the incubation period for this tumour may be 30 to 40 years from first exposure, directly relevant information about shipyard employment was not available. The information which was obtained is summarized in Table 3 and shows that 22 of the 25 cases had been employed in the shipyard at some time and 17 were employed there at the time of onset of their symptoms. Of the 7 cases who were employed in 'clean' work recently or when they retired, 2 had done dustier work within the last 10 years and only 3 were always in 'clean' occupations. Of the 5 cases who were no longer employed by the shipyard 4 had been employed in dusty work and in the other case (No. 17) the nature of his work was not known. The 3 men never employed in the shipyard had all had dusty occupations but in only one (case 23) was there an obvious source of asbestos. Table 4 relates the number of cases in each exposure group to the total number of men employed by the shipyard at the time of the study. This gives an approximate estimate of the number of cases in relation to the population at risk. Occupational groups II and IV, both known to have had some exposure to asbestos, showed the greatest number of cases $(1.6$ and $1.9 \%)$. Groups I and III showed 0.6 and $0.9 \%$ whereas group V showed only $0.32 \%$. The mean number for all workers during the seven-year period was $0.68 \%$.

For Holland as a whole the attack rate for primary pleural tumours was 0.63 per 100000 men per year between 1958 and 1965 . The attack rate for all the shipyard workers appears to be $0.68 \%$ in seven years or about 100 per 100000 men per year. Those with some exposure to asbestos dust appear to have an attack rate at least twice this (group II 230 and group IV 280).

Since the original analysis five further mesotheliomas have been detected up to August 1970, two of which have not yet been confirmed histologically, partly because of a reluctance to perform biopsies which may cause distressing spread of the tumour. Three of the five cases had worked in the shipyard. 

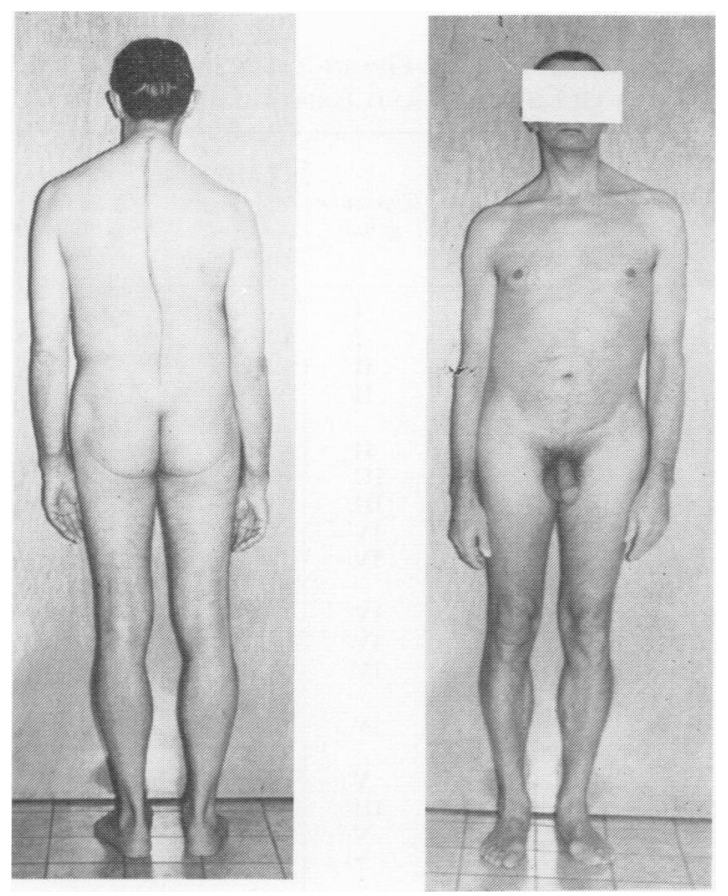

FIG. 1. Patient born in 1906, started work in shipyard age 24 as a pipe worker in completion department (exposure group II). Remained in this work and was a foreman when he developed his first symptoms early in 1966. Until that time he had enjoyed good health. Complained of cough and pain in right chest; chest radiograph showed free fluid and basal atelectasis. Large volume of bloody fluid removed, no malignant cells found, culture sterile. Pain and breathlessness were relieved temporarily but returned a few months later. More fluid was removed but no malignant cells were found. Bronchogram revealed collapse with no obstruction or bronchiectasis; the right hemithorax already showed a marked reduction in size. Later the pleura became densely thickened and only small volumes of fluid $(200 \mathrm{ml})$ were aspirated. Pleural biopsy confirmed the presence of a mesothelioma. By February 1967 the right hemithorax was grossly contracted. He was readmitted to hospital in May 1967 with evidence of spread to the left lung and peritoneum. He died in June and necropsy confirmed the clinical and biopsy diagnosis. The lungs contained much iron pigment as well as asbestos bodies which were shown on electron microscopy to be formed on both chrysotile and amphibole asbestos (Stumphius and Meyer, 1968).

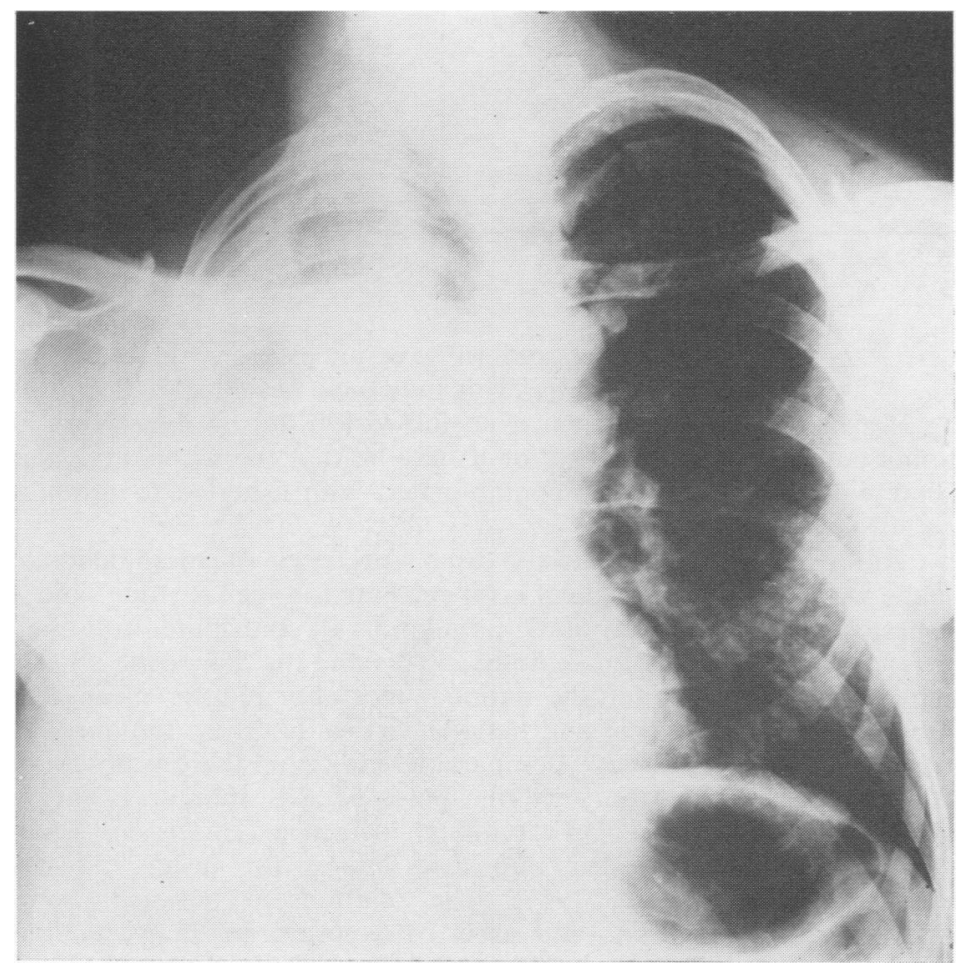

FIG. 2. Postero-anterior chest radiograph of patient shown in Figure 1. 
TABLE 3

Mesothelioma Cases in Walcheren showing Occupation and Exposure Group on 2 September 1967, or at Date of Retirement or Death, and Previous Occupation and Exposure Group

\begin{tabular}{|c|c|c|c|c|c|c|}
\hline $\begin{array}{l}\text { Case } \\
\text { no. }\end{array}$ & $\begin{array}{l}\text { Occupation on } 2 \text { Sept. } 1967, \\
\text { retirement or death }\end{array}$ & $\begin{array}{l}\text { Exposure } \\
\text { group }\end{array}$ & Previous occupation & $\begin{array}{l}\text { Exposure } \\
\text { group }\end{array}$ & $\begin{array}{l}\text { Clinical } \\
\text { diagnosis } \\
\text { histol. } \\
\text { confirmed }\end{array}$ & $\begin{array}{c}\text { Royal } \\
\text { Schelde } \\
\text { employment } \\
(y r)\end{array}$ \\
\hline $\begin{array}{r}1 \\
2 \\
3 \\
4 \\
5 \\
\\
6 \\
7 \\
8 \\
9 \\
10\end{array}$ & 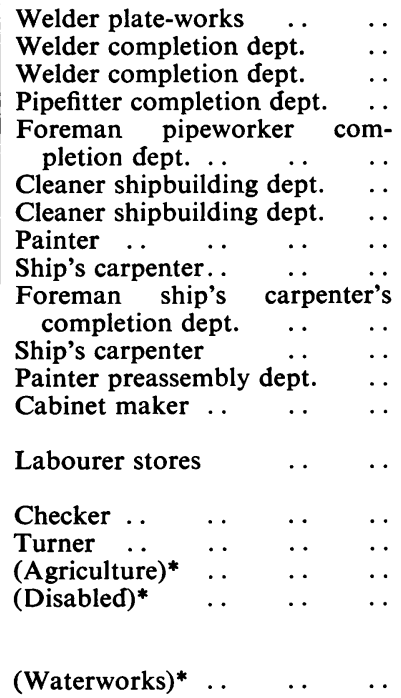 & $\begin{array}{c}\text { I } \\
\text { II } \\
\text { II } \\
\text { II } \\
\text { II } \\
\text { V } \\
\text { V } \\
\text { IV } \\
\text { IV } \\
\text { IV } \\
\text { IV } \\
\text { III } \\
\text { V } \\
\text { V } \\
\text { V } \\
\text { V } \\
\text { - }\end{array}$ & 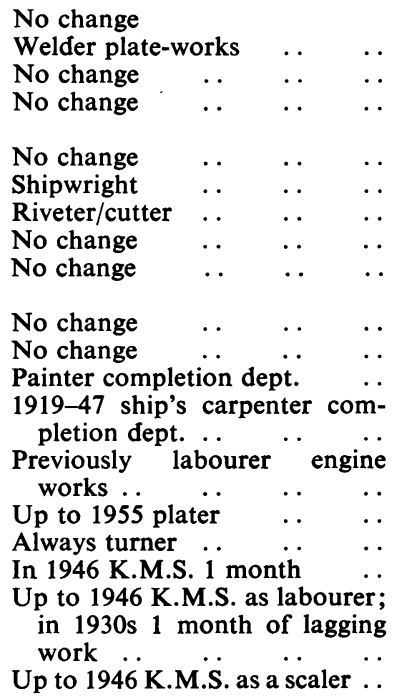 & $\begin{array}{l}\text { I } \\
\text { II } \\
\text { II } \\
\text { II } \\
\text { III } \\
\text { III } \\
\text { IV } \\
\text { IV } \\
\text { IV } \\
\text { IV } \\
\text { IV } \\
\text { IV } \\
\text { V } \\
\text { III } \\
\text { V } \\
? \\
\text { V and III } \\
\text { III }\end{array}$ & $\begin{array}{l}+ \\
+ \\
+ \\
+ \\
+ \\
+ \\
+ \\
+ \\
+ \\
+ \\
+ \\
+ \\
+ \\
+ \\
+ \\
+ \\
+ \\
+ \\
+ \\
+ \\
+\end{array}$ & $\begin{array}{l}40 \\
50 \\
20 \\
32 \\
\\
32 \\
40 \\
43 \\
34 \\
25 \\
\\
36 \\
40 \\
19 \\
\\
43 \\
\\
41 \\
50 \\
36 \\
<1\end{array}$ \\
\hline $\begin{array}{l}20 \\
21 \\
22\end{array}$ & 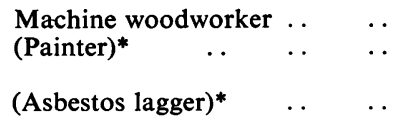 & $\begin{array}{l}\mathrm{V} \\
-\end{array}$ & $\begin{array}{l}\text { No change } \\
\text { Up to } 1950 \text { K.M.S. } \\
\text { painter } \\
\text { Up to } 1926 \text { K.M.S. as a riveter }\end{array}$ & $\begin{array}{l}\text { V } \\
\text { IV } \\
\text { III }\end{array}$ & $\begin{array}{l}- \\
-\end{array}$ & $\begin{array}{r}41 \\
19 \\
4\end{array}$ \\
\hline $\begin{array}{l}23 \\
24 \\
25\end{array}$ & $\begin{array}{l}\text { (Engine room mechanic)* } \\
\text { (Sand and grit blaster)* }^{*} \\
\text { (Foundry moulder)* }^{*}\end{array}$ & 二 & $\begin{array}{l}\text { No change } \\
\text { No change } \\
\text { No change }\end{array}$ & - & $\begin{array}{l}+ \\
+ \\
+\end{array}$ & $\overline{-}$ \\
\hline
\end{tabular}

(occupation)* $^{*}$ not at Royal Schelde (K.M.S.).

\section{Discussion}

The investigation shows that the finding of asbestos bodies in the sputum and of mesothelioma is more frequent among shipyard workers who are exposed to asbestos dust at work. Asbestos insulation workers were excluded from the study and occupational enquiry indicated that none of the workers surveyed had had heavy exposure to asbestos dust. Their exposure to dust appears to have occurred during completion or repair work when insulation was being carried out. In one of the groups all the sputa examined contained asbestos bodies and the attack rate for mesothelioma appears to have been about 300 times that expected for Holland as a whole. However, while these workers were exposed to more asbestos than the rest, all groups of shipyard workers appeared to have had some exposure to asbestos and to have an excessive incidence of mesothelioma. This may have been due to the movement of men from job to job during their years in the shipyard, or it may be that the whole area was sufficiently contaminated with asbestos to produce this effect.

The special search for cases of mesothelioma, good medical arrangements for such a study, and a relatively static population all contributed to a high level of case finding. This and the diagnostic criteria used for the national mortality register mean that the local and national figures for these tumours are not strictly comparable. However, there is no doubt that the local incidence of this tumour is far in excess of the national incidence. This is consistent with other published figures for heavy industry (Gilson, 1966). The relationship between mesothelioma and asbestos exposure in shipyards has 
TABLE 4

Mesothelioma Cases with a Royal Schelde CONNEXION AND EXPOSURE GROUP ACCORDING to NATURe OF WORK IN THE PAST

\begin{tabular}{|c|c|c|c|c|}
\hline $\begin{array}{c}\text { Exposure } \\
\text { group }\end{array}$ & $\begin{array}{c}\text { No. of } \\
\text { persons } \\
\text { employed } \\
2 \text { Sept. } \\
1967\end{array}$ & $\%$ & $\begin{array}{c}\text { No. of } \\
\text { meso- } \\
\text { theliomas }\end{array}$ & $\begin{array}{c}\text { Attack } \\
\text { rate } \\
\text { per } \\
100\end{array}$ \\
\hline $\begin{array}{c}\text { I Iron vapour } \\
\text { II Rust and some } \\
\text { asbestos } \\
\text { III Iron vapour and } \\
\text { rust .. } \\
\text { IV Some asbestos but } \\
\text { little iron } \\
\text { vapour or rust } \\
\text { V Clean work .. }\end{array}$ & $\begin{array}{l}329 \\
188 \\
424\end{array}$ & $\begin{array}{r}10 \cdot 5 \\
6 \cdot 1 \\
13 \cdot 6 \\
\\
10 \cdot 0 \\
59 \cdot 8\end{array}$ & $\begin{array}{l}2 \\
3 \\
4\end{array}$ & $\begin{array}{r}0.61 \\
1 \cdot 59 \\
0.94 \\
\\
1.92 \\
0.32\end{array}$ \\
\hline Total & 3,102 & 100 & 21 & $\begin{array}{l}\text { Mean } \\
0.68\end{array}$ \\
\hline
\end{tabular}

been reported frequently (Elmes and Wade, 1965; Harries, 1968; Sheers and Templeton, 1968) from the United Kingdom. More recently a similar situation has been reported from Hamburg (Dalquen, Dabbert, and Hinz, 1969). Stössel (1970) found 27 cases of mesothelioma between 1964 and 1969 in Wilhelmshaven, the majority having worked in the local naval dockyard.

Although asbestosis was found among the insulation workers in the shipyard there were no mesotheliomas in this occupational group. The youngest patient with a mesothelioma detected in the present study was aged 57 when he died. It is possible that insulation workers die of asbestosis or primary bronchial carcinoma before they reach the age at which mesothelioma is most frequent.

The type of asbestos and the presence of other materials adherent to the asbestos dust, such as metal particles, mineral oils, etc., has been considered in the aetiology of mesothelioma (Harington and Roe, 1965; Commins and Gibbs, 1969; Dixon, Lowe, Richards, and Stokinger, 1969). The Walcheren study shows large amounts of iron oxides in the sputum and lungs of the shipyard workers and in patients dying from mesothelioma. Although crocidolite contains more iron and has been regarded as more likely to cause mesothelioma in humans than other types, Wagner and Berry (1969) have shown that both chrysotile and crocidolite can cause mesotheliomas in animals. In shipbuilding the iron vapour and rust can be inhaled separately from the asbestos dust in many situations.

On Walcheren the source of asbestos dust has been insulation work in the shipyard, the spraying of asbestos (a technique much used formerly) being particularly responsible for the pollution of the atmosphere in ships. Current policy is to employ asbestos-free materials as far as possible. Stone wool, polyurethane foam, ceramic fibre material, etc. have proved feasible substitutes. But unfortunately the effect of this change has been counteracted by the increased use of asbestos-containing materials for other purposes. Fireproof plaster board (e.g., Marinite) which contains asbestos is used in the construction of living accommodation (cabins, dining saloons, etc.) on board ship. This work is done by carpenters and it is impossible to prevent the escape of asbestos into the atmosphere when this type of plaster board is being used. This increases the group of workmen exposed to asbestos in the shipyard.

It is highly desirable that research be carried out to find a suitable substitute for asbestos in making equally strong fireproof board. Here lies a task for the present-day technologist. This is one example from the field of shipbuilding but plenty of others can be found as the uses of asbestos are so manifold that the mineral can be encountered in the most unexpected places.

It is not surprising that mesothelioma is now being found in relation to various industries; it is the consequence of occupational exposure 30 to 40 years ago. Since those days the use of asbestos has increased vastly. So many processes involve the use of asbestos that it is impossible to ensure that the mineral is never released into the atmosphere either as a result of wear and tear or for some other reason.

The author believes that this mineral, which is practically indestructible as far as the human organism is concerned, might become an environmental factor for the whole population. He fears that because of this, in the near future, diffuse mesothelioma will become more prevalent among groups of the population without direct industrial exposure to asbestos in the sense that this has been recognized in the past. In this situation the increase in world production of asbestos from 0.5 to 4 million tons per year between 1940 and 1970 may give rise to concern in the future.

Dr. R. L. Zielhuis, Professor of Industrial Hygiene at the University of Amsterdam has been a great support to me.

The continual interest and assistance of the pathologists, Drs. H. T. Planteydt and F. B. Bronkhorst, have been indispensable. The same applies to the Walcheren physicians, Drs. L. P. Roegholt, P. H. Postma, B. Uyterlinden, and J. L. van Ligten.

Mr. C. M. Zweedijk and Mr. T. A. Toorenburgh, of the Royal Schelde medical service in Flushing (Neth.), have carried out a great deal of exacting work on behalf of this inquiry.

Mrs. M. B. Quast of Flushing (Neth.), has been responsible for the careful translation. 


\section{References}

Commins, B. T., and Gibbs, G. W. (1969). Contaminating organic material in asbestos. Brit. J. Cancer, 23, 358-362.

Dalquen, P., Dabbert, A. F., and Hinz, I. (1969). Zur Epidemiologie der Pleuramesotheliome. Prax. Pneumol., 23, 547-558.

Dixon, J. R., Lowe, D. B., Richards, D. E., and Stokinger, H. E. (1969). The role of trace metals in chemical carcinogenesis-asbestos cancers. In Trace Substances in Environmental Health, edited by Delbert D. Hemphill, vol. 2, pp. 547-558. University of Missouri.

Elmes, P. C., and Wade, O. L. (1965). Relationship between exposure to asbestos and pleural malignancy in Belfast. Ann. N.Y. Acad. Sci., 132, art. 1, 549-557.

Gilson, J. C. (1966). Health hazards of asbestos. Trans. Soc. occup. Med., 16, 62-74.

Harington, J. S., and Roe, F. J. C. (1965). Studies of carcinogenesis of asbestos fibers and their natural oils. Ann. N.Y. Acad. Sci., 132, 439-450.
Harries, P. G. (1968). Asbestos hazards in naval dockyards. Ann. occup. Hyg., 11, 135-145.

Sheers, G., and Templeton, A. R. (1968). Effects of asbestos in dockyard workers. Brit. med. J., 3, 574-579.

Stössel (1970). Personal communication.

Stumphius, J., and Meyer, P. B. (1968). Asbestos bodies and mesothelioma. Ann. occup. Hyg., 11, 283-293.

Wagner, J. C., and Berry, G. (1969). Mesotheliomas in rats following inoculation with asbestos. Brit. J. Cancer, 23, 567-581.

—_, Sleggs, C. A., and Marchand, P. (1960). Diffuse pleural mesothelioma and asbestos exposure in the north western Cape Province. Brit. J. industr. Med., 17, 260-271.

Working Group on Asbestos and Cancer (1965). Report and recommendations of the working group on Asbestos and Cancer convened under the auspices of the Geographical Pathology Committee of the International Union against Cancer. Arch. Environm. Hlth, 11, 221-229. Brit. J. industr. Med., 23, 165-171.

Received for publication December 15, 1969. 